\title{
Optimization of Enzymatic Synthesis of Betulinic Acid Amide in Organic Solvent by Response Surface Methodology (RSM)
}

\author{
Nurul Atikah Amin Yusof ${ }^{1}$, Nursyamsyila Mat Hadziri, ${ }^{, *}$, Siti Efliza Ashari ${ }^{2}$, \\ Nor Suhaila Mohamad Hanapi ${ }^{3}$, and Rossuriati Dol Hamid ${ }^{3}$ \\ ${ }^{1}$ School of Chemistry and Environment, Faculty of Applied Sciences, Universiti Teknologi MARA, \\ 40450 Shah Alam, Selangor, Malaysia \\ ${ }^{2}$ Department of Chemistry, Faculty of Science, Universiti Putra Malaysia, 43400 Serdang, Selangor, Malaysia \\ ${ }^{3}$ Faculty of Applied Sciences, Universiti Teknologi MARA, 40450 Shah Alam, Selangor, Malaysia
}

\section{* Corresponding author:}

tel: $+6012-4897915$

email: nursyamsyila@salam.uitm.edu.my

Received: April 20, 2018

Accepted: November 28, 2018

DOI: $10.22146 /$ ijc.34903

\begin{abstract}
Optimization of the lipase-catalyzed enzymatic synthesis of betulinic acid amide in the presence of immobilized lipase, Novozym 435 from Candida antartica as a biocatalyst was studied. Response surface methodology (RSM) and 5-level-4-factor central-composite rotatable design (CCRD) were employed to evaluate the effects of the synthesis parameters, such as reaction time (20-36 h), reaction temperature (37$45{ }^{\circ} \mathrm{C}$ ), substrate molar ratio of betulinic acid to butylamine (1:1-1:3), and enzyme amounts (80-120 mg) on the percentage yield of betulinic acid amide by direct amidation reaction. The optimum conditions for synthesis were: reaction time of $28 \mathrm{~h}$ $33 \mathrm{~min}$, reaction temperature of $42.92^{\circ} \mathrm{C}$, substrate molar ratio of 1:2.21, and enzyme amount of $97.77 \mathrm{mg}$. The percentage yield of actual experimental values obtained $65.09 \%$ which compared well with the maximum predicted value of $67.23 \%$. The obtained amide was characterized by GC, GCMS and ${ }^{13} C N M R$. Betulinic acid amide (BAA) showed better cytotoxicity compared to betulinic acid as the concentration inhibited $50 \%$ of the cell growth $\left(I_{50}\right)$ against $M D A-M B-231$ cell line $\left(I C_{50}<30 \mu \mathrm{g} / \mathrm{mL}\right)$.
\end{abstract}

Keywords: central composite rotatable design (CCRD); Novozym 435; betulinic acid amide; response surface methodology (RSM)

\section{- INTRODUCTION}

Betulinic acid is a natural triterpene with extraordinarily high activity against human melanoma and is found throughout the plant kingdom of genus Betula, Ziziphus, Syzigium, Diospyros, and Paeonia. Triterpene, which is a compound made of 6 isoprene building units has a wide spectrum of pharmacological activities which are the most noteworthy as antiviral, antiinflammatory, antiulcerogenic, antimicrobial, anticarcinogenic and most importantly anticancer activity [1]. Betulinic acid was known to induce apoptosis selectively in tumor cells lines. This acid acts as a promising antitumor agent due to lack of toxicity towards normal cells. This feature makes betulinic acid unique in comparison to the compounds that are currently used in cancer therapy, such as taxol, camptothecin, ellipticine, etoposide, vinblastine, and vincristine. All these antitumor compounds are very toxic, and they inhibit replication of both cancer and normal cells [2]. The modification or introduction of polar groups, such as phthalates, amino acids or sugar moieties at the C-3 and C-28 positions of betulinic acid in certain cases may enhance its property for drug development and its anticancer activities [3].

Betulinic acid has three active sites, C-3 hydroxyl group, C-20 alkene and C-28 carboxyl group which is suitable for derivatization. A modest series of C-28 betulinic acid derivatives had been synthesized and tested for biological activity. In all cases, a C-28 carbonyl was found essential for preserving cytotoxicity. A series 
of C-28 amino acid conjugates have also been examined for their cytotoxic properties. Several of these derivatives, such as the leucine, alanine, and valine methyl esters and the glycine free acid conjugate, were noted to exhibit melanoma-specific cytotoxic properties similar to betulinic acid. In addition, the amino acid conjugates displayed improved water solubility profiles when compared to betulinic acid [4].

According to Sarek et al. [1], amides represent another type of carboxylic acid derivative. Their antitumor activity is usually high, and their hydrophilicity makes their use in vivo tests very easy. A very complex SARS study about the cytotoxic activity of conjugates of betulinic acid with natural amino acids along with the toxicity study on fibroblasts and basic studies of solubility has been reported by Willman et al. [5]. The best results against MEL-2 cell line were found using conjugates of betulinic acid with alanine. Recent studies have shown that betulinic acid exhibits potent cytotoxic activity specific for melanoma cells both in vitro and in vivo. Numerous papers over the past years aimed for the elucidation of the mode of action, as its anticancer activity, is linked to its ability to induce apoptotic cell death in cancer cells [6].

The novelty of this study was to investigate the interaction of variables for the best production of betulinic acid amide, using Response Surface Methodology (RSM) as compared to the conventional method (parameter-at-one-time) which was expensive and time-consuming. The major disadvantage of conventional method is that it does not include interactive effects amongst the variables. Eventually, it does not depict the complete effects of the parameters on the process. In order to overcome this problem, an optimization study using RSM has been applied. The advantage of RSM is to reduce the number of experiment trials needed to evaluate multiple parameters and their interactions. RSM is useful for developing, improving and optimizing the response variables which treatments are from a continuous range of values.

RSM is essentially a particular set of mathematical and statistical methods for designing experiment, building models, evaluating the effect of variables and identifying the optimum condition of variables to predict targeted responses. The main advantage of RSM is the reduced number of experiment trials needed to evaluate multiple factors and their interactions. Hence, RSM provides an effective tool for investigating the aspects affecting the desired response if there are many factors and interactions in the experiment. RSM has been reported to be successfully applied in various research areas, and mostly in the area of enzymatic synthesis. The works that have been carried out using RSM were the enzymatic synthesis of wax esters [7-8]; [9] and the enzymatic synthesis of dilauryl adipate ester [10]. Pey et al. [11] carried out a study using RSM in order to identify the influence of different variables and to evaluate simultaneous effects of more significant variables on droplet size of nanoemulsions that have been prepared by the step-wise addition of one component to the others at a constant temperature.

\section{- EXPERIMENTAL SECTION}

\section{Materials}

Novozym 435 which is Candida antartica lipase B immobilized on a macroporous acrylic resin was purchased from Novo Nordisk A/S (Denmark). Betulinic acid was isolated from the Malaysian Callistemon sp. as reported in [12]. Butylamine, ethyl acetate, chloroform, hexane, and methanol were purchased from Merck Germany. All other reagents were of analytical grade.

\section{Instrumentation}

\section{Characterization of $B A A$}

${ }^{13} \mathrm{C}$ NMR spectra were recorded on BRUKER NMR spectrometer instrument operating at the frequency of $600 \mathrm{MHz}$. The sample was weighed approximately at 10$20 \mathrm{mg}$ and dissolved in a deuterated solvent, pyridine. Betulinic acid amide formation was confirmed by gas chromatography from Agilent technologies 6890 series which was equipped with non-polar HP-5 capillary column. Nitrogen was used as a carrier gas with a flow rate of $1.0 \mathrm{~cm}^{3} \mathrm{~min}^{-1}$. The injector and the detector were set at $300{ }^{\circ} \mathrm{C}$. The initial temperature of the column was $100^{\circ} \mathrm{C}$ for $4 \mathrm{~min}$, and then increased with a flow rate of $11^{\circ} \mathrm{C} \mathrm{min}^{-1}$ up to $300^{\circ} \mathrm{C}$. 


\section{MTT cytotoxicity assay}

The cytotoxicity of the sample against the cancer cell was determined by using the MTT assay (3-[4,5dimethylthiazol-2-yl]-2,5-diphenyltetrazolium bromide). Pure betulinic acid and BAA are screened for cytotoxicity in vitro against MCF-7 (Human breast adenocarcinoma cancer, 3T3 (Mouse embryonic fibroblast), MDA-MB231 (human breast adenocarcinoma) and A549 (lung cancer) cell lines. The cytotoxicity was recorded as the drug concentration causing $50 \%$ growth inhibition of the tumor cells ( $\mathrm{IC}_{50}$ value).

\section{Procedure}

\section{Enzymatic amidation}

Enzymatic synthesis of BAA as illustrated in Fig. 1 was performed in a $20 \mathrm{~mL}$ capped reactions vial. To a solution mixture of betulinic acid $(22.8 \mathrm{mg}, 0.05 \mathrm{mmol})$, butylamine with different molar ratios (mmol betulinic acid/ mmol butylamine; 1:1-1:3), different amounts of Novozym 435 (80-120 mg), and chloroform and $n$-hexane were added as a solvent media. The reaction mixture was magnetically stirred $(150 \mathrm{rpm})$ at different reaction temperatures $\left(37-45^{\circ} \mathrm{C}\right)$ and reaction times $(20-$ $36 \mathrm{~h}$ ). The progress of the reaction was monitored using thin layer chromatography (TLC) on silica gel plates which were eluted with a mixture of $n$-hexane/ethyl acetate $(7: 3, \mathrm{v} / \mathrm{v})$ as the eluent system. The plates were visualized under the UV lamp and/or potassium permanganate $\left(\mathrm{KMnO}_{4}\right)$ stain.

\section{Experimental design and statistical analysis}

A 5-level-4-factor central composite rotatable design (CCRD) was employed in this study. The fractional factorial design consisted of 16 factorial points, 8 axial points (two axial points on the axis of each design variable at a distance of 2 from the design center), and 6 center points. The variables and their levels selected for the study are given in Table 1.

To avoid being bias, all 30 runs were performed in a random order. The regression analysis, analysis of variance (ANOVA) and response surface plots were generated using the Design Expert Software (version 7.0.0) from Stat-Ease Inc. (Minneapolis, MN, USA). This design was used to fit the second-order model to the independent variables using the Eq. 1.

$\mathrm{Y}=\beta_{0}+\sum_{\mathrm{i}=1}^{\mathrm{k}} \beta_{\mathrm{i}} \mathrm{X}_{\mathrm{i}}+\sum_{\mathrm{i}=1}^{\mathrm{k}} \beta_{\mathrm{ii}} \mathrm{X}_{\mathrm{i}}^{2}+\sum_{\mathrm{i}}^{\mathrm{k}-1} \sum_{1 \leq \mathrm{i} \leq \mathrm{j}}^{\mathrm{k}} \beta_{\mathrm{ij}} \mathrm{X}_{\mathrm{i}} \mathrm{X}_{\mathrm{j}}+\varepsilon$

where $\mathrm{Y}$ is the independent variable (percentage yield) to be modeled, $X_{i}$ and $X_{j}$ are the independent variables (factors), $\beta_{0}, \beta_{\mathrm{i}}, \beta_{\mathrm{ii}}$ and $\beta_{\mathrm{ij}}$ are the regression coefficient of
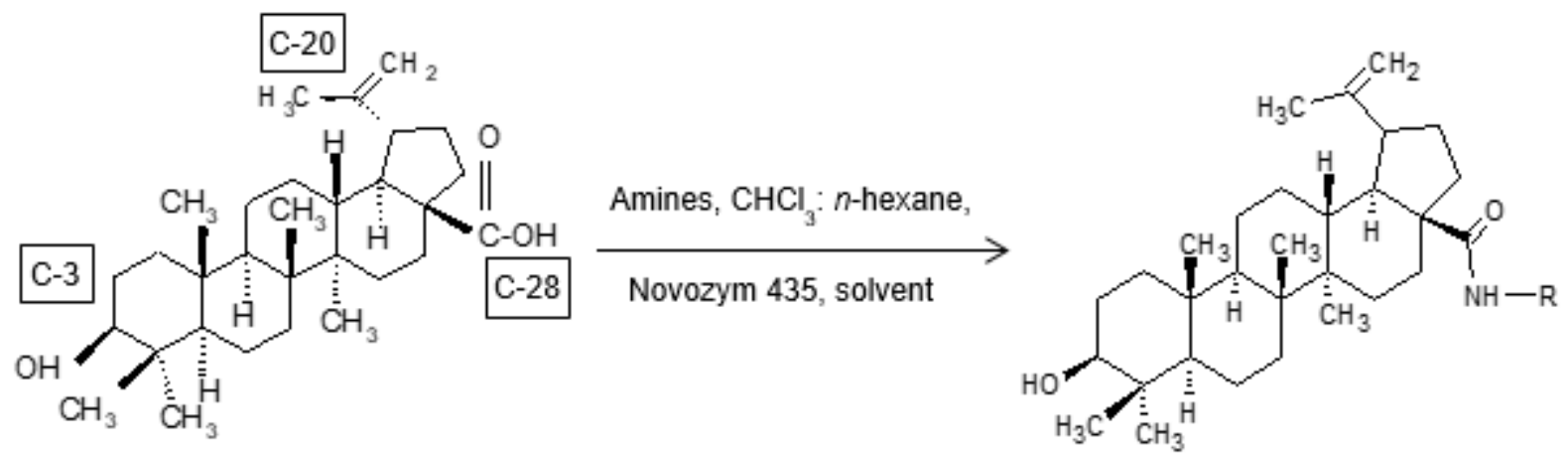

Fig 1. Enzymatic synthesis of betulinic acid amide (BAA)

Table 1. Range of variables for the experimental design

\begin{tabular}{lccccc}
\hline \multirow{2}{*}{ Variables } & \multicolumn{5}{c}{ Levels } \\
\cline { 2 - 6 } & -2 & -1 & 0 & +1 & +2 \\
\hline Reaction time (h), A & 20 & 24 & 28 & 32 & 36 \\
Reaction temperature $\left({ }^{\circ} \mathrm{C}\right), \mathrm{B}$ & 37 & 39 & 41 & 43 & 45 \\
Enzyme amount (mg), C & 80 & 90 & 100 & 110 & 120 \\
Substrate molar ratio (mmol), D & 1 & 1.5 & 2 & 2.5 & 3 \\
\hline
\end{tabular}


the model, $\varepsilon$ is the residual associated with the experiments and $\mathrm{k}$ is the number of parameters tested $(\mathrm{k}=4)$.

\section{- RESULTS AND DISCUSSION}

\section{Model Fitting and Analyses of Variance (ANOVA)}

The experimental and predicted data for lipasecatalyzed of betulinic acid amide are tabulated in Table 2 . Fitting of the data to various models (linear, two factorial, quadratic and cubic) and their subsequent ANOVA showed that reactions of betulinic acid and butylamine were most suitably described with the quadratic polynomial model. The quadratic polynomial model is shown in Eq. 2 where A is the time; B is the temperature; $\mathrm{C}$ is the amount of enzyme and $\mathrm{D}$ is the substrate molar ratio.

Yield $\%=+67.02-0.30 \mathrm{~A}+1.17 \mathrm{~B}-0.39 \mathrm{C}-0.41 \mathrm{D}$
$+0.97 \mathrm{AB}-2.08 \mathrm{AC}+1.05 \mathrm{AD}-0.54 \mathrm{BC}+5.06 \mathrm{BD}$
$-0.38 \mathrm{CD}-6.03 \mathrm{~A}^{2}-3.79 \mathrm{~B}^{2}-2.17 \mathrm{C}^{2}-2.49 \mathrm{D}^{2}$

Table 3 shows the analysis of variance to prove the significance of the quadratic model of the enzymatic reaction. The model F-value of 4.34 implies that the model is significant and the lack-of-fit F-value of 0.58 shows that the lack-of-fit is not significant relative to pure error. There is only a $0.01 \%$ chance that this large

Table 2. Central composite rotatable design of betulinic acid amide

\begin{tabular}{|c|c|c|c|c|c|c|}
\hline \multirow{2}{*}{ Run } & \multirow{2}{*}{$\begin{array}{c}\text { Reaction } \\
\text { time, } h(\mathrm{~A})\end{array}$} & \multirow{2}{*}{$\begin{array}{c}\text { Reaction } \\
\text { temperature, }{ }^{\circ} \mathrm{C}(\mathrm{B})\end{array}$} & \multirow{2}{*}{$\begin{array}{c}\text { Amount of } \\
\text { enzyme, } \mathrm{mg}(\mathrm{C})\end{array}$} & \multirow{2}{*}{$\begin{array}{c}\text { Substrate mole ratio, } \\
\text { mmole (D) }\end{array}$} & \multicolumn{2}{|c|}{ Yield (\%) } \\
\hline & & & & & Actual & Predicted \\
\hline 1 & 36 & 41 & 100 & 2.0 & 40.60 & 41.23 \\
\hline 2 & 28 & 41 & 100 & 2.0 & 66.00 & 67.02 \\
\hline 3 & 24 & 39 & 110 & 2.5 & 48.00 & 47.70 \\
\hline 4 & 24 & 43 & 90 & 2.5 & 55.35 & 55.59 \\
\hline 5 & 24 & 43 & 110 & 1.5 & 50.85 & 50.68 \\
\hline 6 & 32 & 43 & 110 & 1.5 & 44.84 & 45.77 \\
\hline 7 & 24 & 39 & 90 & 2.5 & 44.40 & 43.99 \\
\hline 8 & 32 & 39 & 90 & 2.5 & 48.00 & 47.71 \\
\hline 9 & 24 & 39 & 90 & 1.5 & 56.14 & 56.28 \\
\hline 10 & 24 & 43 & 110 & 2.5 & 56.00 & 57.12 \\
\hline 11 & 24 & 39 & 110 & 1.5 & 61.00 & 61.50 \\
\hline 12 & 28 & 41 & 100 & 1.0 & 58.00 & 57.89 \\
\hline 13 & 28 & 41 & 100 & 2.0 & 68.70 & 67.02 \\
\hline 14 & 32 & 43 & 90 & 1.5 & 51.20 & 51.04 \\
\hline 15 & 28 & 41 & 100 & 2.0 & 65.80 & 67.02 \\
\hline 16 & 32 & 43 & 90 & 2.5 & 63.16 & 63.18 \\
\hline 17 & 28 & 45 & 100 & 2.0 & 55.00 & 54.18 \\
\hline 18 & 32 & 39 & 110 & 1.5 & 53.40 & 52.70 \\
\hline 19 & 28 & 41 & 120 & 2.0 & 58.00 & 57.54 \\
\hline 20 & 28 & 41 & 100 & 2.0 & 67.60 & 67.02 \\
\hline 21 & 32 & 39 & 110 & 2.5 & 42.90 & 43.10 \\
\hline 22 & 32 & 39 & 90 & 1.5 & 56.40 & 55.80 \\
\hline 23 & 28 & 41 & 100 & 3.0 & 56.20 & 56.24 \\
\hline 24 & 32 & 43 & 110 & 2.5 & 57.00 & 56.40 \\
\hline 25 & 20 & 41 & 100 & 2.0 & 43.12 & 42.43 \\
\hline 26 & 28 & 41 & 100 & 2.0 & 67.20 & 67.02 \\
\hline 27 & 28 & 41 & 100 & 2.0 & 66.80 & 67.02 \\
\hline 28 & 24 & 43 & 90 & 1.5 & 47.32 & 47.64 \\
\hline 29 & 28 & 37 & 100 & 2.0 & 48.76 & 49.52 \\
\hline 30 & 28 & 41 & 80 & 2.0 & 58.71 & 59.10 \\
\hline
\end{tabular}


value could have occurred due to the noise in this experiment.

The quadratic regression model indicated that the determination of coefficient $\mathrm{R}^{2}$ value was 0.9936 , which suggested that $99.36 \%$ of the total variation could be illustrated by the fitted quadratic polynomial model. Fig. 2 depicts the good correlation between the actual and predicted yield for betulinic acid amide using Novozym 435 in a solvent system and the linear distribution is indicated of a well-fitted model.

Table 3. ANOVA for the quadratic model developed for synthesis of Betulinic acid amide

\begin{tabular}{lccrrr}
\hline Source & Sum of Squares & Degree of freedom & Mean Square & F-Value & P-value \\
\hline Model & 1943.13 & 14 & 138.80 & 167.13 & $<0.0001$ \\
A-Time & 2.16 & 1 & 2.16 & 2.60 & 0.1276 \\
B-Temperature & 32.57 & 1 & 32.57 & 39.22 & $<0.0001$ \\
C-Amount enzyme & 3.68 & 1 & 3.68 & 4.43 & 0.0525 \\
D-Substrate molar ratio & 4.12 & 1 & 4.12 & 4.96 & 0.0417 \\
$\mathrm{AB}$ & 15.05 & 1 & 15.05 & 18.13 & 0.0007 \\
$\mathrm{AC}$ & 69.14 & 1 & 69.14 & 83.25 & $<0.0001$ \\
$\mathrm{AD}$ & 17.60 & 1 & 17.60 & 21.19 & 0.0003 \\
$\mathrm{BC}$ & 4.73 & 1 & 4.73 & 5.70 & 0.0306 \\
$\mathrm{BD}$ & 409.46 & 1 & 409.46 & 493.04 & $<0.0001$ \\
$\mathrm{CD}$ & 2.28 & 1 & 2.28 & 2.75 & 0.1183 \\
$\mathrm{~A}^{2}$ & 1087.85 & 1 & 1087.85 & 1309.92 & $<0.0001$ \\
$\mathrm{~B}^{2}$ & 394.55 & 1 & 394.55 & 475.09 & $<0.0001$ \\
$\mathrm{C}^{2}$ & 129.63 & 1 & 129.63 & 156.09 & $<0.0001$ \\
$\mathrm{D}^{2}$ & 169.75 & 1 & 169.75 & 204.40 & $<0.0001$ \\
Residual & 12.46 & 15 & 0.83 & - & - \\
Lack of Fit & 6.69 & 10 & 0.67 & 0.58 & 0.7835 \\
Pure Error & 5.77 & 5 & 1.15 & - & - \\
Corrected Total & 1955.59 & 29 & - & - & - \\
\hline
\end{tabular}

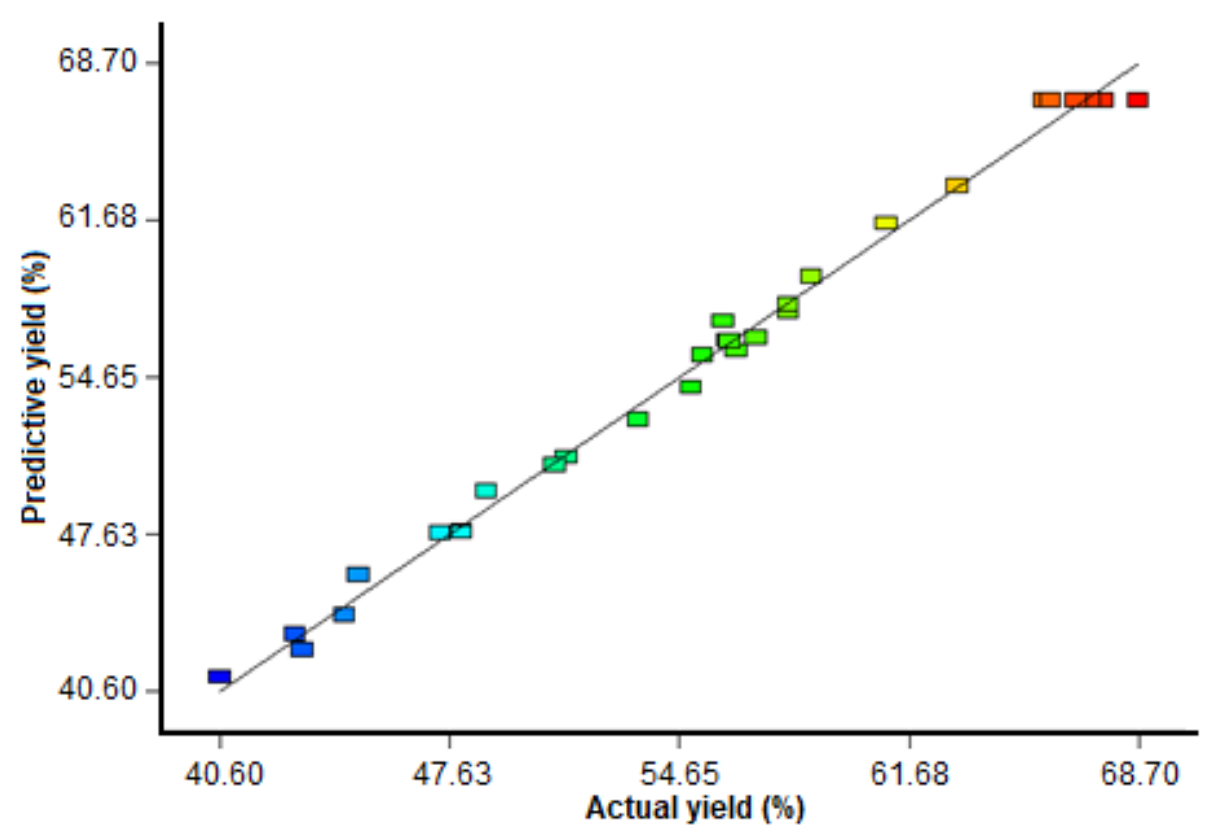

Fig 2. Correlation of actual and predicted values of yield by the response surface model 


\section{Interactive Effects of Parameters}

Response surface plot predicted for the interaction between reaction time (A), and reaction temperature (B) was illustrated in Fig. 3(a), with the enzyme amount was fixed at their center point of $100 \mathrm{mg}$, molar ratio 1:2. The percentage yield increased from reaction time 24 to $28 \mathrm{~h}$. However, the yield decreased when reaching $32 \mathrm{~h}$. The enzymatic reaction with a temperature of $41{ }^{\circ} \mathrm{C}$ and time $28 \mathrm{~h}$ led to a maximum yield up to $67.02 \%$. The increase in yield indicated that the reaction had achieved the equilibrium state, which means the rate of forwarding reaction was equivalent to the rate of backward reaction [13].

By increasing the temperature from 39 to $41^{\circ} \mathrm{C}$, the percentage yield increased. However, the yield kept decreasing as the temperature of reaction reached $43{ }^{\circ} \mathrm{C}$. The decrease in yield after $28 \mathrm{~h}$ is due to the fact that the rate of backward reaction overcomes the rate of amidation. Based on [14], Novozym 435 was optimally used at temperatures between 40 to $60^{\circ} \mathrm{C}$, because higher
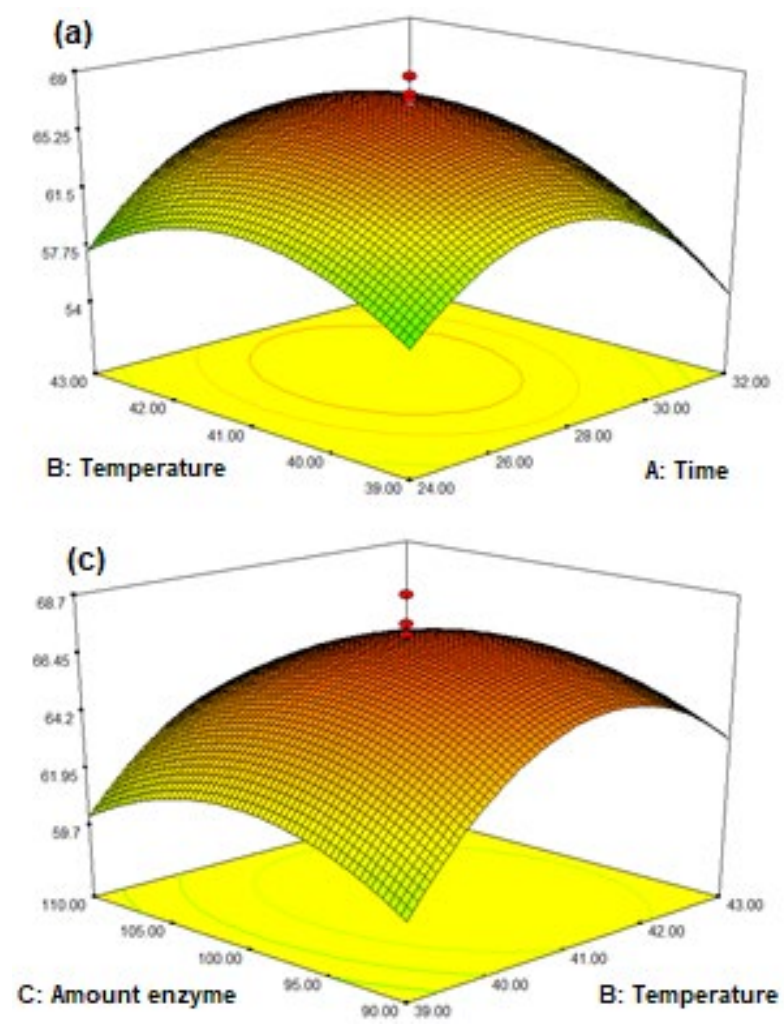

temperatures of reaction tend to induce enzyme inactivation due to the denaturation process [15].

Fig. 3(b) shows the effects of varying reaction times and the amounts of enzyme on the synthesis of betulinic acid amide. The maximum yield of betulinic acid amide (67.02\%) was achieved at reaction time $28 \mathrm{~h}, 41{ }^{\circ} \mathrm{C}$ and substrate molar ratio 1:2. However, at the highest amount of Novozym 435 used $(120 \mathrm{mg})$ and the reaction time of $28 \mathrm{~h}$, the percentage yield was decreased to $58.0 \%$. The decrease in the yield is probably due to substrate limitations during the reaction. At this point, all substrates are bound to the enzyme, and further addition of any enzyme molecules in the reaction may cause a decrease in the yield [16].

The effects of reaction temperature and the amount of enzyme are shown in Fig. 3(c). The maximum yield of betulinic acid amide was obtained (67.02\%) at $100 \mathrm{mg}$ enzyme, and at reaction temperature $41^{\circ} \mathrm{C}$ for $28 \mathrm{~h}$. This effect of reaction temperature can be explained by its
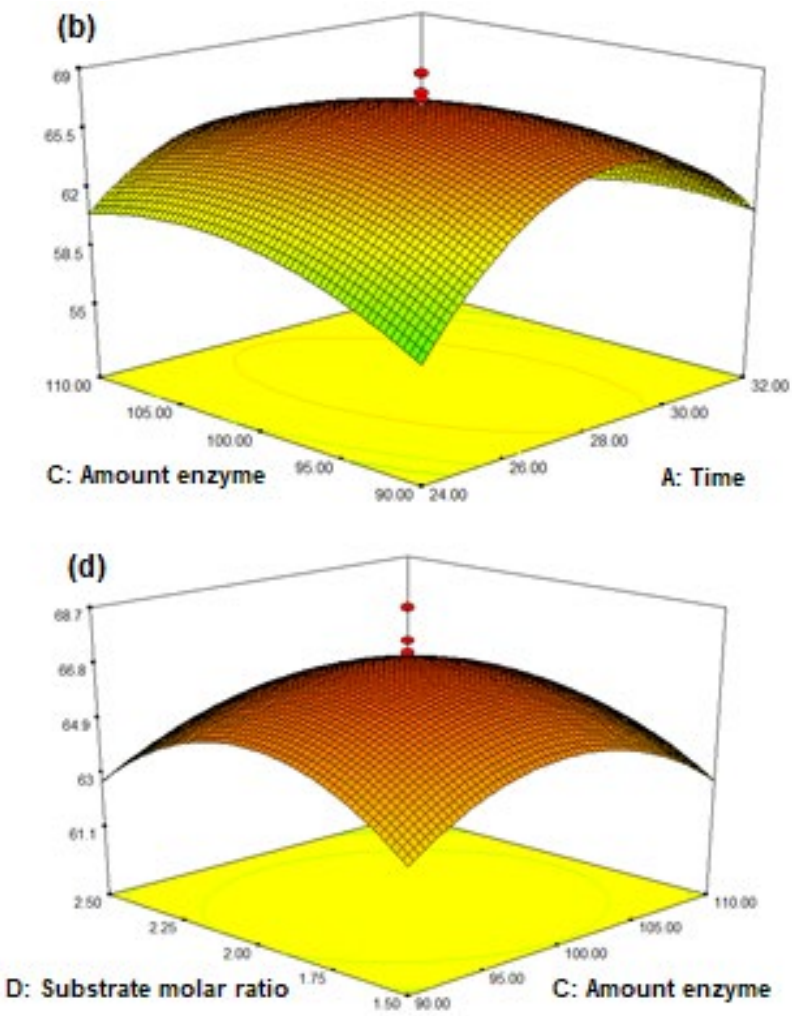

Fig 3. Three-dimensional response surface plots. (a) reaction time $(\mathrm{h})$ versus reaction temperature $\left({ }^{\circ} \mathrm{C}\right)$, (b) reaction time $(\mathrm{h})$ versus enzyme amount $(\mathrm{mg})$, (c) reaction temperature $\left({ }^{\circ} \mathrm{C}\right)$ versus enzyme amount $(\mathrm{mg})$ and $(\mathrm{d})$ enzyme amount $(\mathrm{mg})$ versus substrate molar ratio (mmole) on percentage yield as response 
Table 4. Optimum conditions for Novozym 435 catalyzed synthesis of betulinic acid amide

\begin{tabular}{cccccccc}
\hline $\begin{array}{c}\text { Run } \\
\text { no. }\end{array}$ & $\begin{array}{c}\text { Reaction } \\
\text { time, } \mathrm{h}(\mathrm{A})\end{array}$ & $\begin{array}{c}\text { Reaction } \\
\text { temperature, }{ }^{\circ} \mathrm{C}(\mathrm{B})\end{array}$ & $\begin{array}{c}\text { Enzyme amount, } \\
\mathrm{mg}(\mathrm{C})\end{array}$ & $\begin{array}{c}\text { Substrate molar } \\
\text { ratio, mmol (D) }\end{array}$ & Yield (\%) & Difference \\
\hline 1 & 28.33 & 41.92 & 97.77 & $1: 2.21$ & 65.09 & 67.23 & 2.14 \\
\hline
\end{tabular}

effect on substrate solubility and its direct influence on the reaction and the enzyme [17]. According to [18] the enzyme amount does not affect the percentage yield because a large amount of enzyme can contribute to a large excess of enzyme active site and it would not be exposed to the substrate due to possible protein aggregation.

Fig. 3(d) depicts the effects of varying amounts of the enzyme and substrate molar ratio on amidation reaction at $28 \mathrm{~h}$ and reaction temperature $41{ }^{\circ} \mathrm{C}$. At low substrate molar ratio and small amounts of the enzyme, the percentage yield was decreased. Reaction with amounts of the enzyme $(110 \mathrm{mg})$ and 1:2 molar ratios showed the maximum percentage yield $(67.02 \%)$. The percentage yield decreased as the molar ratio increased up to 1:2.5. According to [19], a large excess of enzymes led to a lower conversion because enzyme molecules can associate with each other, covering the active site that cannot accommodate the substrate, and therefore reducing the yield of the product. In Michaelis-Menten systems, the reaction rate is dependent on the enzyme to substrate ratio: at a low enzyme to substrates ratios, the substrate is in excess and so an increase in enzyme content enhances the reaction rate. But at a very high or maximum amount of enzyme to substrate ratios, all the available substrates are forming the enzyme/substrate complex, and so the additional enzyme molecules (active sites) cannot further improve the reaction rate. Additionally, since the initial rate does not increase linearly with the enzyme added, the product yield per gram enzyme would be lower as the enzyme quantity is raised [20].

\section{Optimum Conditions}

The optimum conditions can indicate the optimal conditions parameters to obtain the highest percentage yield of lipase-catalyzed synthesis of betulinic acid amide.
The expected maximum yield of $67.23 \%$ at reaction conditions of $28.33 \mathrm{~h}, 42.92{ }^{\circ} \mathrm{C}, 97.77 \mathrm{mg}$ and 1:2.21 was predicted by using the optimized function of the Design Expert Software. As shown in Table 4, the actual experimental value obtained was $65.09 \%$ with a small difference of 2.14. Therefore, this result confirmed the validity of the quadratic model and demonstrated that the response surface methodology could be applied effectively to optimize the lipase-catalyzed synthesis of betulinic acid amide.

\section{Analysis of the Reactions Product}

The identification of the product was confirmed by TLC, GC, FT-IR, and NMR. The BAA product obtained after the purification appeared to be yellowish crystal with a melting point in the range of $\left(308-310^{\circ} \mathrm{C}\right)$. TLC analysis was carried out, and the BAA product had $\mathrm{R}_{\mathrm{f}}$ value of 0.88 . The formation of BAA monitored by FTIR showed N-H stretching at 3365 and $1686 \mathrm{~cm}^{-1}$ indicated the presence of the carbonyl group $(\mathrm{C}=\mathrm{O})$ of amides. The ${ }^{13} \mathrm{C}-\mathrm{NMR}$ spectrum of BAA exhibited the presence of the amide carbonyl compound which resonated at $\delta 178.0 \mathrm{ppm}$. The presence of the double bond in the lupene skeleton was proven by the signals at $\delta 151.1 \mathrm{ppm}$ and $109.7 \mathrm{ppm}$. The presence of alkyl carbons of butylamine was confirmed by the signals of C-1' C-2', C-3' and C-4' at $\delta 38.7,30.97,21.3$ and 14.20, respectively.

Fig. 4 depicts the chromatogram of the betulinic acid amide (BAA) that showed the retention time of $6.451 \mathrm{~min}$ when analyzed by gas chromatography (GC). An internal standard (Glyceryl tributyrate) was identified at retention time $5.841 \mathrm{~min}$ between the two substrates, betulinic acid and butylamine with retention times of $6.256 \mathrm{~min}$ and $2.835 \mathrm{~min}$ respectively. The mass spectrum of BAA shows a molecular ion peak at $\mathrm{m} / \mathrm{z} 511$. 


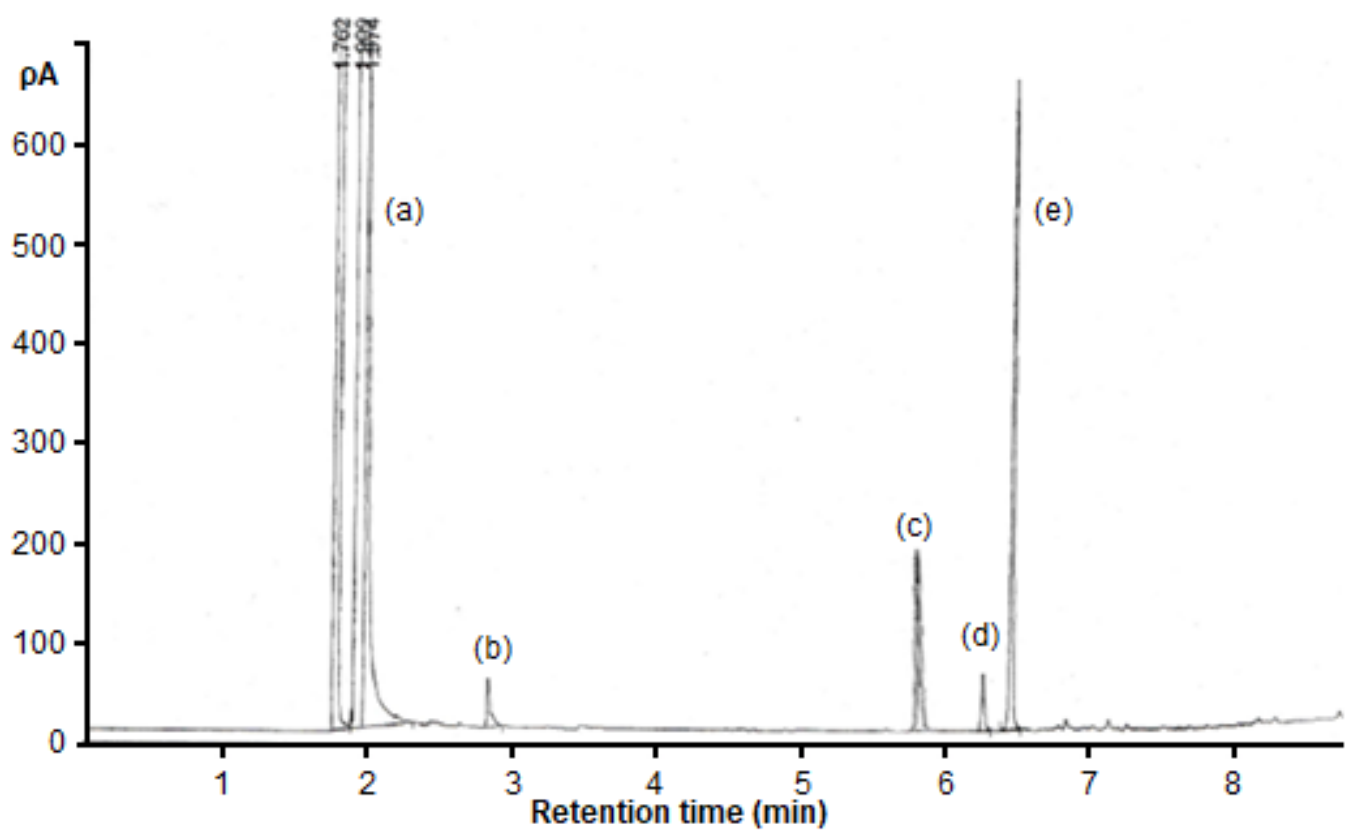

Fig 4. GC chromatogram of BAA. Peaks (a) Tetrahydrofuran (THF), (b) Butylamine, (c) Internal standard (Glyceryl tributyrate), (d) Betulinic acid, (e) Betulinic acid amide (BAA)

Betulinic acid amide (BAA) was screened for cytotoxicity in vitro against MCF-7, 3T3, MDA-MB-231, A549 cancer cell lines. BAA showed better cytotoxicity against MDA-MB-231 cell line $\left(\mathrm{IC}_{50}<30 \mu \mathrm{g} / \mathrm{mL}\right)$ compared to betulinic acid itself.

\section{- CONCLUSION}

In this study, the optimization of lipase-catalyzed amidation of BAA in a solvent media was successfully performed using the response surface methodology (RSM). The $\mathrm{R}^{2}$ value of 0.9936 indicated the quadratic model fitted with the experimental findings of the present study. A yield of $65.09 \%$ obtained from the optimum conditions can be used for future upscaling process. The identification structure of BAA was revealed by using the $\mathrm{GC},{ }^{13} \mathrm{C}$ NMR and GC-MS. Based on the in vitro cytotoxic results, it was observed that the modification of betulinic acid at C-28 position using amines, in certain cases, increased the anticancer activity.

\section{- ACKNOWLEDGMENTS}

The authors wish to thank Prof. Dr. Hj. Faujan bin Ahmad, Prof. Dr. Mahiran Basri, all the staff in the Faculty of Applied Sciences of Universiti Teknologi MARA (UiTM), and the staff in the Department of Chemistry of
Universiti Putra Malaysia (UPM) for the help given in this study. This work was supported by the Research Management Institute of Universiti Teknologi MARA [600-IRMI/DANA5/3/LESTARI(0090/2016]. The proof reading of this article was provided by Dr. Fatimah Dinna Mohd Din from the Academy of Language Studies of Universiti Teknologi MARA (UiTM).

\section{- REFERENCES}

[1] Sarek, J., Kvasnica, M., Vlk, M., and Urban, M., 2011, "The Potential of Triterpenoids in the Treatment of Melanoma" in Research on Melanoma - A Glimpse into Current Directions and Future Trends, Eds., Murph, M., IntechOpen, UK, 125158.

[2] Zuco, V., Supino, R., Rhigetti, S.C., Cleris, L., Marchesi, E., Gambacorti-Passerini, C., and Formelli, F., 2002, Selective cytotoxicity of betulinic acid on tumor cell lines, but not normal cells, Cancer Lett., 175 (1), 17-25.

[3] Gauthier, C., Legault, J., Lavoie, S., Rondeau, S., Tremblay, S., and Pichette, A., 2008, Synthesis of two natural betulinic acid saponins containing $\alpha-\mathrm{L}-$ rhamnopyranosyl-( $1 \rightarrow 2)$ - $\alpha$-L-arabinopyranose and 
their analogues, Tetrahedron, 64 (30-31), 7386-7399.

[4] Cichewicz, R.H., and Kouzi, S.A., 2004, Chemistry, biological activity, and chemotherapeutic potential of betulinic acid for the prevention and treatment of cancer and HIV infection, Med. Res. Rev., 24 (1), 90114.

[5] Willman, M., Wacheck, V., Buckley, J., Nagy, K., Thalhammer, J., Paschke, R., Triche, T., Jansen, B., and Selzer, E., 2009, Characterization of NVX-207, a novel betulinic acid derived anti-cancer compound, Eur. J. Clin. Invest., 39 (5), 384-394.

[6] Ressmann, A.K., Kremsmayr, T., Gaertner, P., Zirbs, R., and Bica, K., 2017, Toward a benign strategy for the manufacturing of betulinic acid, Green Chem., 19 (4), 1014-1022.

[7] Gunawan, E.R., Basri, M., Rahman, M.B.A., Salleh, A.B., and Rahman, R.N.Z.A., 2005, Study on response surface methodology of lipase-catalyzed synthesis of palm- based wax ester, Enzyme Microb. Technol., 37 (7), 739-744.

[8] Radzi, S.M., Basri, M., Salleh, A.B., Ariff, A., Mohammad, R., Rahman, M.B.A., and Rahman, R.N.Z.A., 2005, Large scale production of liquid wax esters by immobilized lipase, J. Oleo Sci., 54 (4), 203209.

[9] Sin, K.P., Basri, M., Rahman, M.B.A., Salleh, A.B., Rahman, R.N.Z.A., and Ariff, A., 2005, Optimization of palm-based wax esters production using statistical experimental designs, J. Oleo Sci., 54 (10), 519-528.

[10] Rahman, M.B.A., Chaibakhsh, N., Basri, M., Rahman, R.N.Z.R.A., Salleh, A.B., and Radzi, S.M., 2008, Modelling and optimization of lipase catalyzed synthesis of dilauryl adipate ester by response surface methodology, J. Chem. Technol. Biotechnol., 83, 1534-1540.

[11] Pey, C.M., Maestro, A., Solé, I., González, C., Solans, C., and Gutiérrez, J.M., 2006, Optimization of nanoemulsions prepared by low-energy emulsification methods at constant temperature using a factorial design study, Colloids Surf., A, 288 (1-3), 144-150.

[12] Ahmad, F.B., Omar, J., and Ali, A.M., 1999, Chemical examination of local plant: Triterpene from leaf of Malaysian Callistemon speciousus D.E, Ultra Sci., 11, 357-359.

[13] Gunawan, E.R., Basri, M., Rahman, M.B.A., Salleh, A.B., and Rahman, R.N.Z.R.A., 2004, Lipasecatalyzed synthesis of palm-based wax esters, J. Oleo Sci., 53 (10), 471-477.

[14] Lozano, P., De Diego, T., Carrié, D., Vaultier, M., and Iborra, J.L., 2003, Enzymatic ester synthesis in ionic liquids, J. Mol. Catal. B: Enzym., 21 (1-2), 913.

[15] Radzi, S.M., Basri, M., Salleh, A.B., Ariff, A., Mohammad, R., Rahman, M.B.A., and Rahman, R.N.Z.R.A., 2005, High performance enzymatic synthesis of oleyl oleate using immobilized lipase from Candida antartica, Electron. J. Biotechnol., 8 (3), 291-298.

[16] Yasin, Y., Basri, M., Ahmad, F., and Salleh, A.B., 2008, Response surface methodology as a tool to study the lipase-catalyzed synthesis of betulinic acid ester, J. Chem. Technol. Biotechnol., 83 (5), 694-698.

[17] Facioli, N.L., and Barrera-Arellano, D., 2001, Optimisation of enzymatic esterification of soybean oil deoderiser distillate, J. Sci. Food Agric., 81 (12), 1193-1198.

[18] Jumbri, K., Rozy, M.F.A., Ashari, S.E., Mohamad, R., Basri, M., and Masoumi, H.R.F., 2015, Optimisation and characterisation of lipase catalysed synthesis of a Kojic monooleate ester in a solvent-free system by response surface methodology, PLoS ONE, 10 (12), e0144664.

[19] Foresti, M.L., Errazu, A., and Ferreira, M.L., 2005, Effect of several reaction parameters in the solventfree ethyl oleate synthesis using Candida rugosa lipase immobilized on polypropylene, Biochem. Eng. J., 25 (1), 69-77.

[20] Romero, M.D., Calvo, L., Alba, C., Daneshfar, A., and Ghaziaskar, H.S., 2005, Enzymatic synthesis of isoamyl acetate with immobilized Candida antarctica lipase in $n$-hexane, Enzyme Microb. Technol., 37 (1), 42-48. 